\title{
Effects of Biomass Energy on Recycling from a Sustainability Perspective
}

\author{
Fatma Nur Doğar ${ }^{1, *}$ (D), Fatma Didem Tunçez $^{1}$ iD
}

${ }^{1}$ KTO Karatay University, Faculty of Economics and Administrative Sciences, Department of Energy Management, Konya, Karatay, Turkey

\section{Article History}

Received 21 June 2021

Accepted 23 August 2021

First Online 15 November 2021

\section{Corresponding Author}

E-mail:

fatmanurdogar06@gmail.com

\author{
Keywords \\ Fossil Fuels \\ Renewable Energy Sources \\ Biomass \\ Climate Change \\ Zero Waste
}

\begin{abstract}
The need for energy is increasing in parallel with the population and industrialization, which are increasing rapidly year by year in the world. Fossil based fuels have a larger share compared to other energy sources with a ratio of approximately $60 \%$ in the use of primary energy sources. Biomass, which has become an important source in terms of energy efficiency and solutions to environmental problems, stands out among the resources with the most suitable potential to be evaluated. From a sustainability perspective, biomass energy meets approximately $6.4 \%$ of total global energy demand economically and plays an important role with waste management policies to mitigate climate change environmentally. Organic waste and paper account for $65 \%$ of the global waste amount, which can be used to generate energy. In this study, the importance of biomass energy in the energy sector and its impact on the fight against climate change which has both in terms of its potential and in terms of solving environmental problems, has been investigated in the focus of reducing dependence on fossil resources.
\end{abstract}

\section{Introduction}

Sustainable development is a generally accepted concept of climate and environmental policies both nationally and universally. Sustainable development; Without giving dedication to the principle of the use of environmental values and natural resources in a way that does not lead to extravagance, taking into account the rights and benefits of today's and future generations, it is reciprocated in the dictionary as ensuring economic development (Keleş, 1998). The concept of sustainable development, which aims to use natural resources in the most favorable way by taking environmental quality into account, has been discussed in recent years with macroeconomic definitions on different issues within the framework of economic discipline.
The purpose of our work is in line with the definitions we will mention in the first chapter; evaluating biomass energy, which is among the renewable energy sources, from a sustainability perspective; to determine the effects it has on the fight against climate change by reducing the dependence on fossil energy sources and by reassessing waste by recycling. Within the scope of the study, the necessary articles were examined and a qualitative research was carried out. Accordingly, in the first part of the study, the development process of the concept of sustainable development will be discussed and in the second part the focus will be on reducing dependence on fossil resources and focusing on the sustainability of biomass energy. With it, the importance of biomass energy for the world and Turkey will be examined in the balance of supply and demand. From the same perspective, after 
due diligence of biomass energy within the framework of climate change and its effects on recycling.

\section{Development of Sustainable Development Concept}

Although the concept has been emphasized in many ways in international studies, discussions and policies since the 1980s, there has been no consensus on its meaning and definition. According to Freeman and Soete (2003); it is a system that transfers the natural resources and environmental needs of today's and future generations to the next generation without using them irrevocably. Accordingly Tıraş (2012), it is necessary to ensure rational management of natural resources in a way that enables continuous economic development while maintaining human health and natural balance, and to address a natural, physical and social policies worthy of future generations together with environmental policies. Definitions point to the existence of economic, social and environmental policies at every stage of development, but state that the basis of meeting human needs on the economic system is based on the ecological system. The point to be emphasized is that the reduction in resources and the destruction caused to the environment can be achieved by $100 \%$ recycling.

The World Commission for Environment and Development was established in 1983 under the leadership of the United Nations (UN) with the environmental and ecological movement that began with environmental damage in the 1960s and the global perception of the damage in the 1970s. The Bruntland Report (Our Common Future), which includes the consensus-accepted definition of sustainable development, was published in 1987 under the chairmanship of Gro Harlem Bruntland. In the report, the concept; It is defined as "Meeting today's needs without compromising the need of future generations to meet their own needs" (UN Documents, 1987).

Accordingly, Hardi and Zdan were examined economically, socially and environmentally in three dimensions in 1997 in order for sustainable development to be successful. These three dimensions of society were considered as a simultaneous but independent process (Figure 1.a) before a common definition of sustainable development was adopted in 1987. However, it became clear that the results that would arise after this approach was a long-term problem for another factor. In this context, there are two different approaches to the concept of sustainable development that develop with the Bruntland Report. The first was introduced by Hart in 1999 (Akgül, 2010). According to Hart (1999), as a result of these three different dimensions being associated with each other (Figure 1.b) the concept of sustainable development as a whole can be mentioned, which is called the "Russian Doll" model. The other approach was put forward by Rydin in 2008. According to Rydin, it has equal weight in the formation of the concept in three dimensions. As a result of the simultaneous execution of these three dimensions, the idea of sustainable development is established (Figure 1.c), which is called the "Three Column Model". It is still the most sought-after model today.

The optimal tool for transferring sustainable development to future generations is the environmental dimension. Despite human activities, the ability of the environment to protect or renew itself is being destroyed, which leads to serious welfare concerns for future generations. In order to better adapt to sustainable development, the objectives and objectives of the concept must be well understood. Nearly 60 objectives for sustainable development have been set by the UN with the Bruntland Report. Improving the quality of growth, ensuring that basic needs are met, balancing the population level, ensuring resource diversity, managing technology, uniting the environment and economy in single digits in the decision-making process are among the main objectives of the report.

The concept of sustainable development, which dates back to the Middle Ages, has recently been

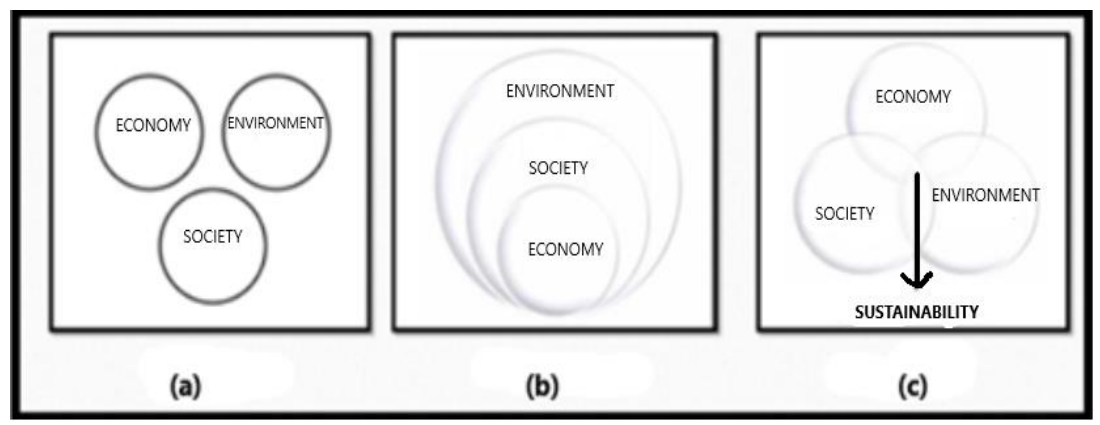

Figure 1. (a): Simultaneous independent processes of sustainable development (b): Russian doll model (c): Three column model. 
frequently used. The concept, which was first used in the fields of agriculture, forestry and fisheries in the early 19th century, has literally started to enter our lives with the steps taken on international platforms in the 20th century the first step in terms of sustainable development was taken through Rachel Carson in order to maintain the natural balance of future generations as the extent of environmental damage began to be perceived in the 1960s. Another step for environmental problems that reached international dimensions in the 1970s was the publication titled "Limits to Growth Secrets of Growth" published by the Roman Club in 1972, which ensured that what needs to be done for the targeted balance between economy, society and the environment is seen on a different scale (Meadows et al., 1972). Sustainable development with the Bruntland Report (Our Common Future), presented to the UN in 1987; the handling of needs on the basis of economics has been recognized as "the process of meeting the needs without sacrificing any means while meeting the needs of today's and future generations" based on the elements of observance of justice on a national and international scale on a generational scale. (Tıraş, 2012). In addition, the concept in the report is associated with the elimination of poverty and the equal distribution of natural resource use.

Another conference for sustainable development, which has become a policy on a global scale, was the " United Nations Conference on Sustainable Development (Rio Conference) " in Rio De Janerio in 1992, attended by the heads of government of 178 countries. With this conference, he drew attention to the right to a quality life with the harmony between mankind and nature (Report of the United Nations Conference on Environment and Development, 1993). At the conference, two key documents were adopted: the Rio Declaration and Agenda 21 (Bozlağan, 2005). After this conference in 1993; The "UN Commission for Sustainable Development" was established to ensure the effective adaptation and monitoring of the principles and provisions adopted at the conference, to strengthen international relations, to rationalize the decision-making mechanisms of governments for the development of environmental issues, and to implement Agenda 21 at 3 levels, national and international. In 1995, the "Population And Development Conference" was held in Cairo and the relationship between population and the sustainable concept was evaluated. The concept of sustainable development was associated with human settlements with the Habitat II in 1996 (Bozlağan, 2005). Decisions and responsibilities for sustainable development were reviewed held by the UN in 1997 in the "Rio+5" meeting five years after the Rio conference. "UN Millennium Summit" was held at 20; and "Istanbul+5" meeting was held in 2001 and the decisions are taken so far regarding the concept of sustainable development were evaluated. (Çamur \& Vaizoğlu, 2007).
Ensuring sustainability in the dimension of economic development and being sensitive to the use of resources in economic activities should be ensured due to the limited reserves of natural resources on a world scale (Kaya \& Tomal, 2011). In this context, the "UN World Sustainable Development Summit" was held in Johannesburg in 2002 on the grounds of a more comprehensive assessment of what should be considered in terms of the use of resources and their impact on the environment. The summit discussed sustainable development, poverty elimination and environmental protection, which are at the heart of the international agenda, and cooperation with various organizations, especially non-governmental organizations. (Yıldırım \& Öner, 2003). Another important point of this summit is that the concept of sustainable development has been the name of a summit for the first time, which has been adopted and understood on a global scale.

The UN has continued to lead international meetings on sustainable development, which are held every two years in the World Urban Form I - II. - III. - IV. and V (2002 - $2004-2006-2008$ - 2010). In line with these international meetings, it emphasizes that the concept of sustainable development in the development of today's society and future generations should be a holistic approach to solving the problems in the environment and development dimension.

The final declaration "The Future We Want" was published at the "United Nations Conference on Sustainable Development" in 2012, also known as "Rio+20". With this declaration, the commitment to implement the decisions taken in previous conferences has been renewed; ensuring that economic, social and environmental factors are aligned with each other for the realization of human beings at the center of sustainable development; it has been noted that it should play an influential role in achieving sustainable development in all segments of society on a global scale.

Coal was first used as an energy source in the UK and then in other countries with the arrival of the Industrial Revolution. However, the share of coal in the energy balance was $10 \%$, while the share of biomass was $90 \%$ in the late 1850 s. Even biomass the heating of houses continued to be used as fuel in areas such as the railway sector and contributed more than coal until the mid-1870s. Biomass continued to meet half of its energy needs, with most of its energy being met by coal until the late 1900s (Özdemir, 2020).

Even if biomass is estimated $10 \%$ share in the energy consumption balance, the consumption model may vary between countries. For example, when industrialized countries use only biomass $3 \%$ when meeting their energy needs; Biomass energy is consumed more to heat houses during the winter months in parts of the UK, North America and Northern Europe. Biomass is considered an auxiliary fuel in both limited reserve and increased price balance of fossil fuels. 


\section{Situaion of Biomass Energy at the World and Turkey Scale}

The world's natural resource is rapidly running out due to the increasing daily energy needs of the worldclass population. The rising level of prosperity with the social and economic development of mankind has led to an increase in the need for energy. Securing energy supply and reducing the share of energy input in climate change is important on the road to a sustainable future. As a natural consequence of this, the world is now expected to move from fossil energy sources to completely renewable energy sources by researching alternative energy sources. The graphical relationship between the consumption of primary energy sources, population and gross domestic product (GDP) is clearly shown in Figure 2. and the same figure shows the data on total energy generation and total electricity consumption. In the period between 2015 and 2019, when a general assessment of the world energy consumption and the economy is made; the world population increased from 7 billion 339 million to 7 billion 674 million, GDP from 75 trillion 218 billion to 87 trillion 735 billion and total energy consumption increased from 2.516 million tons of equivalent oil to 2.589 million tons of equivalent oil (World Energy Consumption Statistics / Enerdata, 2020). This observation is evidence of the relationship between sustainable development and the provision of energy supply.

Renewable energy sources are called renewable energy sources that are unlikely to run out of existing reserves in nature without limited stock on earth and can renew themselves. Evaluating these resources from a sustainability perspective, (Tester et al., 2005) defines sustainable energy as "a harmony between the fair accessibility of energy-intensive goods and services for all people and the protection of the world for future generations". According to the British Petroleum Statistical Review of World Energy 2020 report, fossil fuels account for more than $60 \%$ of the primary energy consumption on the scale of the world regions, which once again recognize the importance of renewable energy sources in terms of expanding energy access, reducing fossil fuel dependence and achieving climate goals (Figure 3 ).

'Biomass, which emerges as the origin of plants and living organisms, is often referred to as plant organisms that store solar energy with the help of photosynthesis. Biomass can also be defined as the total mass that living organisms belonging to a species or a society of various species have at a certain time" (T.C. Enerji ve Tabii Kaynaklar Bakanlığı, 2014).

Biomass, which is mainly based on carbohydrate components, is undergoing both physical and chemical processes and transforms into bioenergy in solid, liquid and gas forms that have commercial properties. Bioenergy; liquid as methanol, ethanol, butanol and biodiesel; gas as methane and hydrogen; it is an energy that can be used as wood and dung in solid and tribune boilers and microbial fuel cells in electricity generation (Acaroğlu, 2008). In short, the energy obtained from organic matter in various ways is called biomass energy (Türkiye Kojenerasyon Derneği, nd).

Biomass energy can be considered in two dimensions, classical and modern. In classic size; it consists of wood and plant/ animal waste confiscated from forest areas for use in incineration. In modern size; it covers plant cultivation (sugarcane, aspire, cocoon, etc.) that has emerged today for wastewater, urban waste, industrial waste, energy production. Biomass energy; it meets approximately $10.4 \%$ of total global energy demand, including $4 \%$ in classical size and $6.4 \%$ in modern size, but accounts for $70 \%$ of renewable energy use for the largest use of heating in a 2021 study (Çolakoğlu et al., 2021).

Biomass use in the fight against climate change. It has positive effects such as reducing greenhouse gas emissions, maintaining air - water - soil quality, biodiversity, high-resource potential, high-capacity power plants and the revival of the economy with the

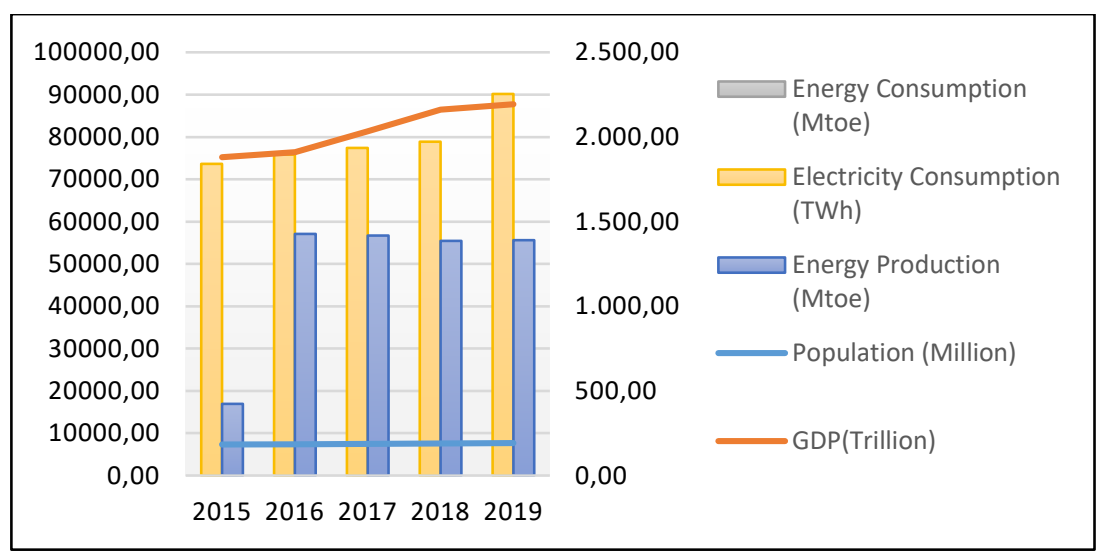

Figure 2. Total Energy Consumption on a World Scale, GDP, Between Population. 


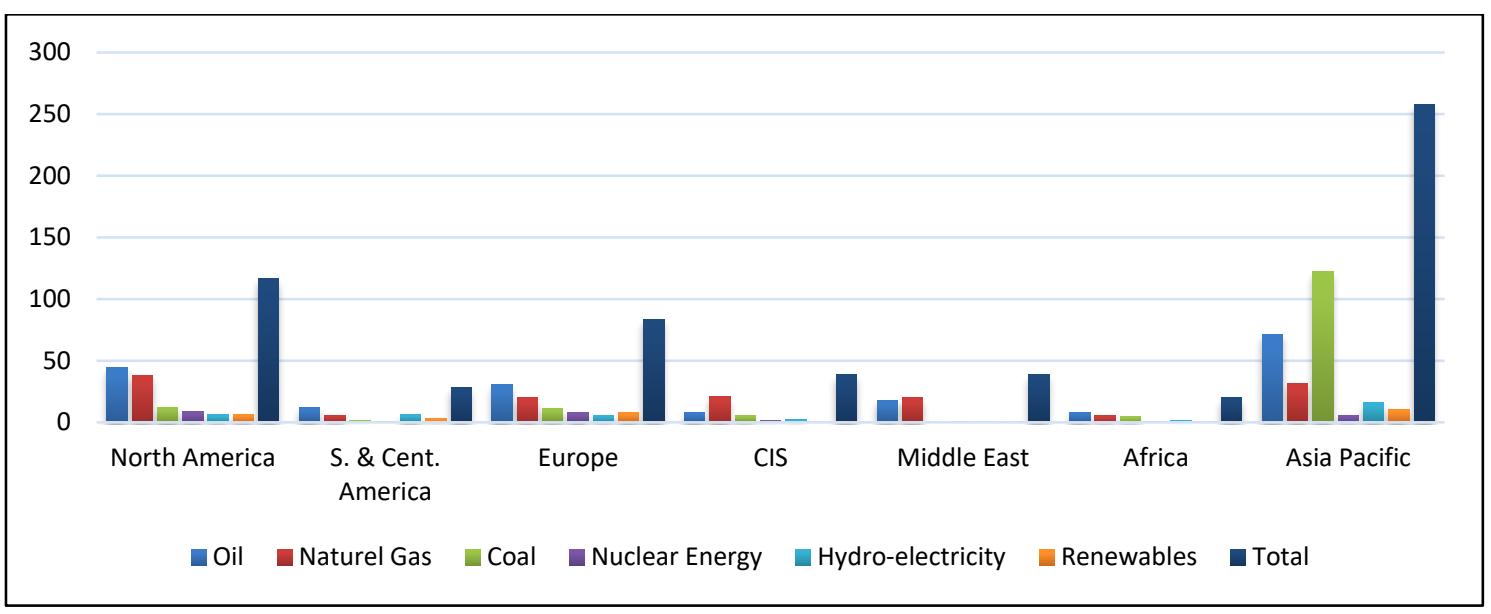

Figure 3. Distribution of primary energy consumption in the world on a resource scale (2019.)

increase of sectors that support bioenergy from a sustainability perspective.

The world-class capacity change in the focus of renewable energy sources is shown in Figure 4. in the Renewable Capacity Statistics 2021 report published by the International Renewable Energy Agency (IRENA). When the bioenergy focus is evaluated, it has increased from $71,745 \mathrm{MW}$ to $126,557 \mathrm{MW}$ in the last 10 years. The sustainability of the supply of energy in the world to be considered together with renewable energy sustainability in general obliges. The installed power balance of biomass energy increased from $816.60 \mathrm{MW}$ in January 2020 to $1115.60 \mathrm{MW}$ in December 2020 in Turkey (Figure 5) (Türkiye Elektrik Iletim A.Ş., 2021). This situation is especially important for importing states such as Turkey, especially considering that it is $90 \%$ dependent on the external energy needs by meeting the use of fossil fuels such as oil and natural gas, reducing dependence on imports and biomass energy as a solution to sustainability problems in terms of resource diversity.

\section{Scrutinizing of Biomass Energy on the Scale of Recycling and Climate Change}

Reliable energy supply in all economies is important for the service areas such as heating, lighting, industrial equipment, transportation, etc. in human life (Bahar et al., 2020). However, from a sustainability perspective, the main goal of energy supply policies should be to minimize climate and environmental threats. In past years, the concept of development on the scale of countries was energy abundance and consumption, while today the concept of development has included the ability to provide energy with more efficient resource understanding and more economical technologies. This perspective brought with it energy security, energy diversity and green environmental policies. In particular, the common basis of these policies is the attempt to mitigate the effects of climate change caused by global warming.

REC Turkey (URL-1 2016), the climate in climate change bedside guide from $A$ to $Z$; It is defined as "in the

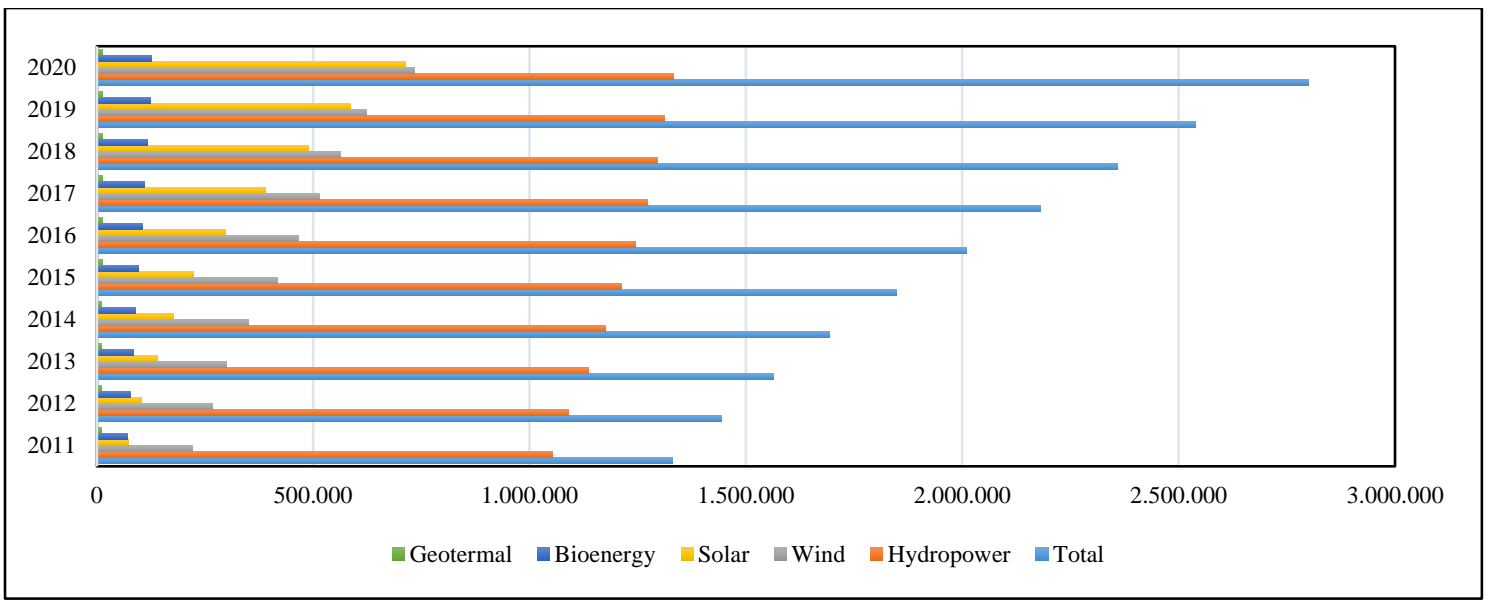

Figure 4. Capacity change of renewable energy sources on a world scale between $2011-2020$ (MW). 
simplest terms, the average condition of all weather conditions experienced or observed anywhere on earth for many years" and, in a more systematic approach, "synthesis (composition) defined by long-term statistics such as variability and average values of atmospheric elements in a given area" (composition)" (Altunok \& Altunok, 2016; Türkeş, 2000).

Apart from environmental discussions on climate change during the Cold War years, it was not on the international agenda until the first half of the 1980s and remained the subject of scientific research only. However, with the increase of natural disasters that are beginning to occur on a world scale, scientific developments have brought the issue to the international agenda. In fact, negotiations and contracts on climate change can be considered as an indication that awareness of the issue is beginning to increase. The negotiations were held respectively; The United Nations Climate Convention, which was held at the Rio World Summit in 1992 and came into force in 1994; It is referred to as the Kyoto Protocol, which came into force in 1997 but came into force in 2005, and the 2015 Paris Climate Summit (COP21), the first global step. According to the Paris Agreement (2015) adopted as a result of COP21, which was attended by 195 countries; it has been accepted that the average temperature increase on a global scale will be well below $2^{\circ} \mathrm{C}$ compared to preindustrial levels, even to make efforts to ensure that the temperature increase does not exceed $1.5^{\circ} \mathrm{C}$, and in the end it will significantly reduce the risks and effects of climate change.

Climate change plays a triggering role in environmental issues. Climate change, as a result of the greenhouse effect thought to be caused by gases released into the atmosphere (Figure 6), brings with it the increase in average temperatures measured on land, sea and air throughout the year on Earth, in other words, global warming (Sağsen, 2016). In order to prevent global warming, the factors that cause it need to be known.

According to data released by NOAA ESRL Global Monitoring Laboratory the concentration of carbon dioxide in the atmosphere reached $419.13 \mathrm{ppm}$ in May 2021 (Figure 7). According to scientists, while the amount of carbon dioxide in the atmosphere should not exceed $350 \mathrm{ppm}$, which corresponds to a temperature increase of $1.5^{\circ} \mathrm{C}$, it should not exceed $450 \mathrm{ppm}$, that is, the red line, which corresponds to a temperature increase of $2^{\circ} \mathrm{C}$, due to the importance of the data announced. However, assuming an increase of approximately $3 \mathrm{ppm}$ each year, it is estimated that the time is running to avoid redness. It may be too late for everything when a temperature increase of $2^{\circ} \mathrm{C}$ is reached.

Studies on the scale of climate change; underlines that it can negatively affect human health, the quality of products produced in agricultural areas, natural habitats, water resources, both directly and indirectly. For example, it has been suggested that human activities such as agriculture and water resources use affected climate change between 1970 and 1980. (Kanat \& Keskin, 2018). In this context, climate change in the agricultural sector can be considered as an environmental limitation. However, while the increasing rise of climate change is an indication that the drought will become unavoidable, it is also stated that the use of technology will not prevent this in the future. (Ausubel \& Biswas, 1980).

In the prevention of climate change caused by global warming, it is necessary to prevent the carbon source in the atmosphere, that is, to look at the earth first. Because the Intergovernmental Panel on Climate Change (IPCC), created in 1988 by the World Meteorology Organization (WMO) and the United Nations Environment Programme (UNEP) to provide scientific findings that all governments can use to

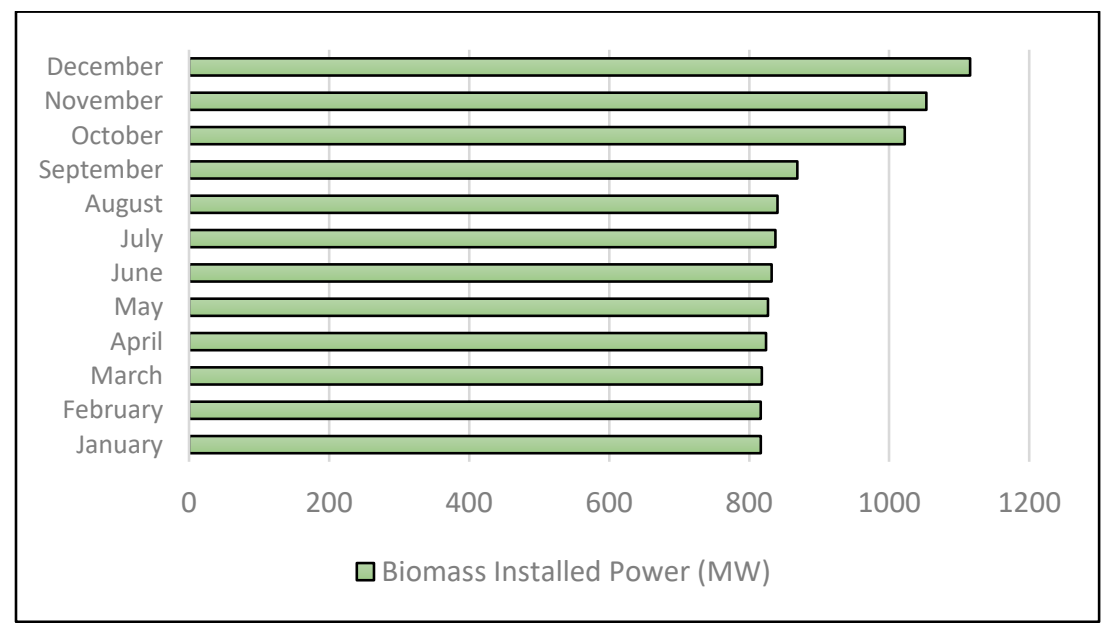

Figure 5. Biomass energy installed power on a month scale in Turkey in 2020 (MW). 
improve climate policies, says that human beings are solely responsible for this climate change at a rate of $95 \%$. According to another study, between 2000 and 2010 , approximately $97 \%$ of the earth's carbon dioxide was naturally emitted and $3 \%$ was emitted into the atmosphere as a result of human activities. (Kanat \& Keskin, 2018). The use of fossil energy resources, which begins with industrialization and disrupts the climate of the world, needs to be reduced, which, as Figure 8 shows, the energy sources that cause $\mathrm{CO}_{2}$ emissions on a world scale are coal, oil and natural gas, respectively.

On the scale of Turkey, the situation is not very different. In the distribution of emissions on a sectoral scale (Figure 9), $72 \%$ is energy-sourced, followed by agriculture with $13.4 \%$, industrial operations and product use with $11.2 \%$, and the waste sector with $3.4 \%$. $\mathrm{CO}_{2}$ emissions take first place with $79 \%$ of the distribution of total emissions on the gas scale (Figure 10). $87.4 \%$ are from the energy sector, $12.3 \%$ from the industrial operations and product use sector, and $0.3 \%$ from the agriculture and waste sectors of the total of $\mathrm{CO}_{2}$ emission ("Sera Gazı Emisyon İstatistikleri, 19902019", 2021).

A study called Climate Analytics aims to stop coalbased electricity generation as a fossil resource in EU and OECD countries by 2030, in China by 2040 and in other countries by 2050 . Even if coal plants start to be closed in many countries, it seems unlikely to meet the $1.5 \mathrm{C}^{\circ}$ targets at this rate. Indeed, in order to achieve the Paris Agreement goal, coal production in the world must be reduced by $5.6 \%$ each year by 2030 , but it has not.

According to the IPCC (2011), sustainable energy policies are among the measures that can be taken to mitigate the effects of global warming and climate

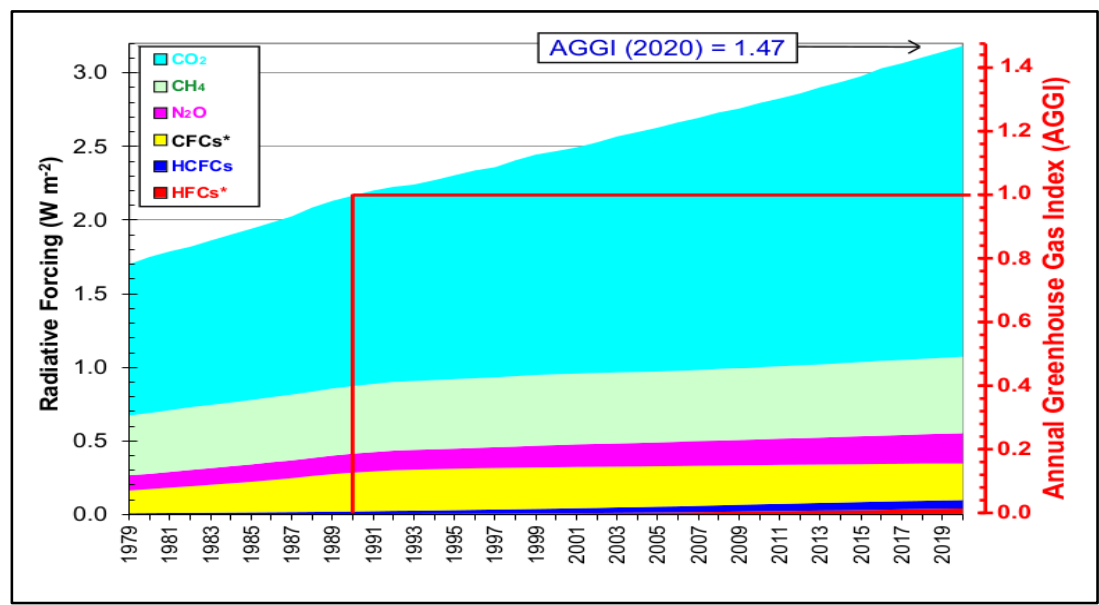

Figure 6. Greenhouse gas heating effect and shares ("NOAA/ESRL Global Monitoring Laboratory - The NOAA annual greenhouse gas index (aggi)", 2021).

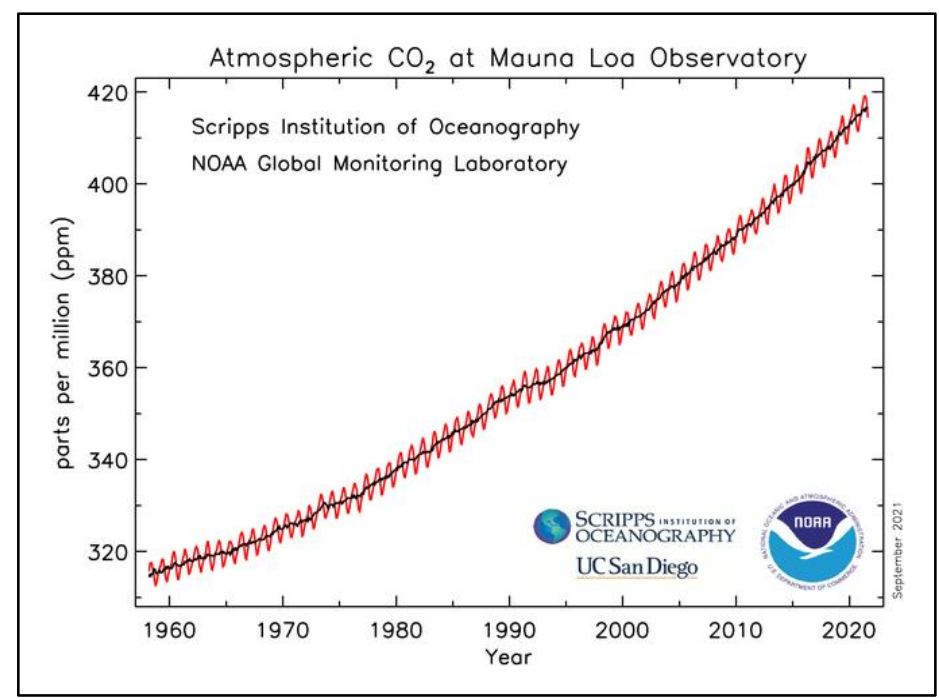

Figure 7. $\mathrm{CO}_{2}$ density on atmospheric scale ("Global Monitoring Laboratory - Carbon Cycle Greenhouse Gases", 2021). 


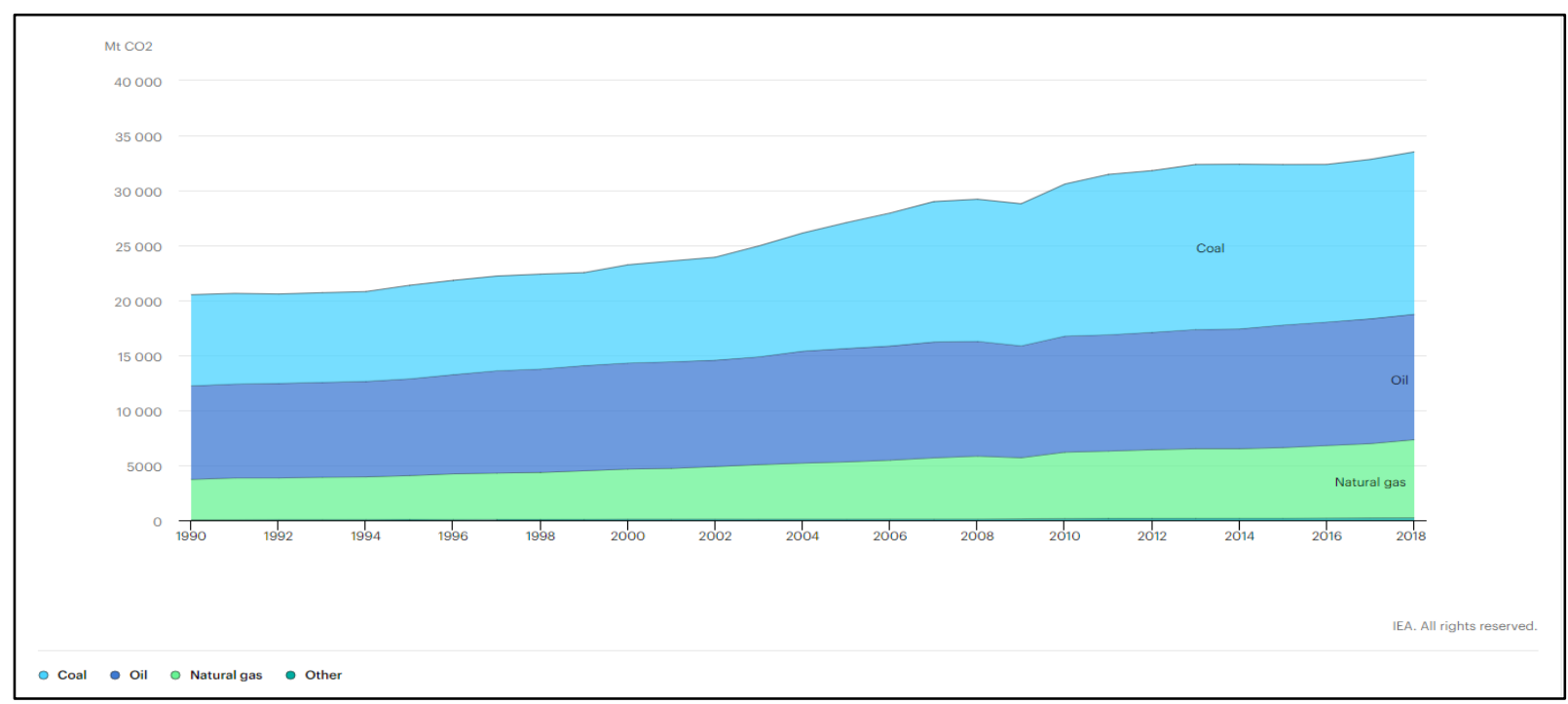

Figure 8. $\mathrm{CO}_{2}$ emissions by energy source, World 1990-2018 ("Data \& Statistics, $\mathrm{CO}_{2}$ emissions, $\mathrm{CO}_{2}$ emissions by energy source - IEA", 2021)

change, with policies on energy management and renewable energy sources at the forefront.

The first solution that comes to mind is to increase the use of renewable energy sources in order to reduce the carbon footprint resulting from the use of energy on a global scale. In order to prevent climate change from creating a catastrophe on a global scale; By 2030, the share of renewable energy sources in energy consumption can be doubled, reducing emissions and adding energy efficiency to the fight, reducing the average rise in global temperature to less than $2^{\circ} \mathrm{C}$ $\left(1.5^{\circ} \mathrm{C}\right)$ (Bayraç, 2010; Doğan, 2011; IPCC., 2011). In addition projections for renewable energy sources are evaluated positively in the Sustainable Development Scenario, which predicts that by 2050, half of the electricity generation will be provided by renewable energy sources according to the International Energy Agency.

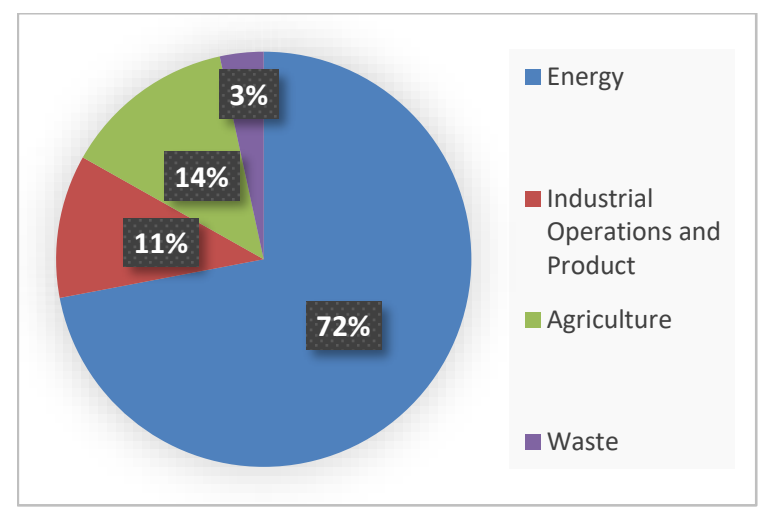

Figure 9. Total emission distribution on a sectoral scale in Turkey $\left(\mathrm{mt} \mathrm{CO}_{2}\right)$.
All kinds of substances that have parts that do not benefit economically can be called waste after being used during the activities of mankind. According to the Waste Management Regulation published in 2015, waste; the manufacturer is defined as any substance or material that is thrown into the environment by the natural or legal person who actually owns it, which is left, must be disposed of. Cardboard, paper, metal, plastic, glass, plant, rubber etc. are included in the waste class. The reassessment and use of these substances can be achieved by recycling. Recycling is expressed as recycling wastes that have the opportunity to be reassessed, both physically and chemically processed and converted into a second raw material, thus bringing them back into manufacturing processes. Protection of natural resources, reduction of energy imports, reduction of carbon emissions, clean environment, soil

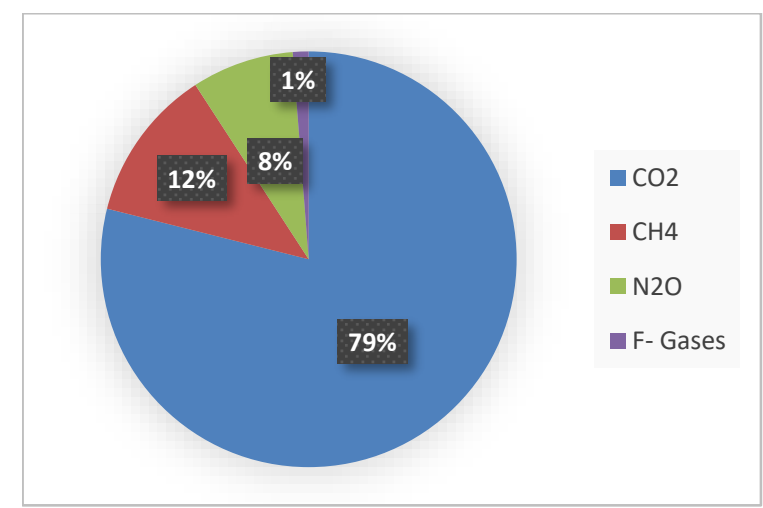

Figure 10. Total emission distribution on the Turkish gases scale $\left(\mathrm{Mt} \mathrm{CO}_{2}\right)$. 
efficiency can be considered among the main benefits of recycling.

Both prosperity and industrialization on a global scale lead to an increase in waste production per capita. The global distribution of waste types is given in Figure 11. Food and plant (organic waste) and waste consisting of paper, cardboard and cardboard substances constitute $61 \%$ of total global waste.

Household waste collected by or on behalf of municipalities in Turkey; approximately 21.6 million tons were sent to regular storage facilities, while 6.5 million tons were sent to municipal landfills and 4.0 million tons to composting facilities; 74 thousand tons were disposed of by various methods such as burning, burial and dumping in the open, according to the Turkish Statistical Institute data, in 2018 (Figure 12).

In parallel, according to the United Nations Waste Report published in 2021, almost $1 / 3$ of the food consumed by human beings on a world scale is wasted and sent to landfills (United Nations Environment Programme, 2021). Numerically, a total of 931 million tons of food are wasted each year, while $61 \%$ of this waste occurs in houses. As stated in the report, Turkey is among the 10 countries with the highest per capita waste; it ranks 3rd, causing 7.7 million tons of food to be thrown away and wasted, equivalent to about $93 \mathrm{~kg}$ of food each year. $5.4 \%$ of consumers throw away the remaining food and $23 \%$ of the food they buy without consuming it, at all in the Turkish Waste Report prepared by the Ministry of Commerce in 2018 (Güzel et al., 2018). According to the Food Safety Association's "Food Loss and Label Reading Survey", households living in a home environment in Turkey waste the most fruits and vegetables with $42 \%$ and milk and dairy products with $41 \%$. According to the same report, the consumer throws away $72 \%$ of the food that is consumable due to the fact that the difference between the last consumption date (STT) and the recommended consumption date (TETT) information is not clearly known.

According to the change in municipal waste between 2010 and 2018 in Figure 12, it is seen that the

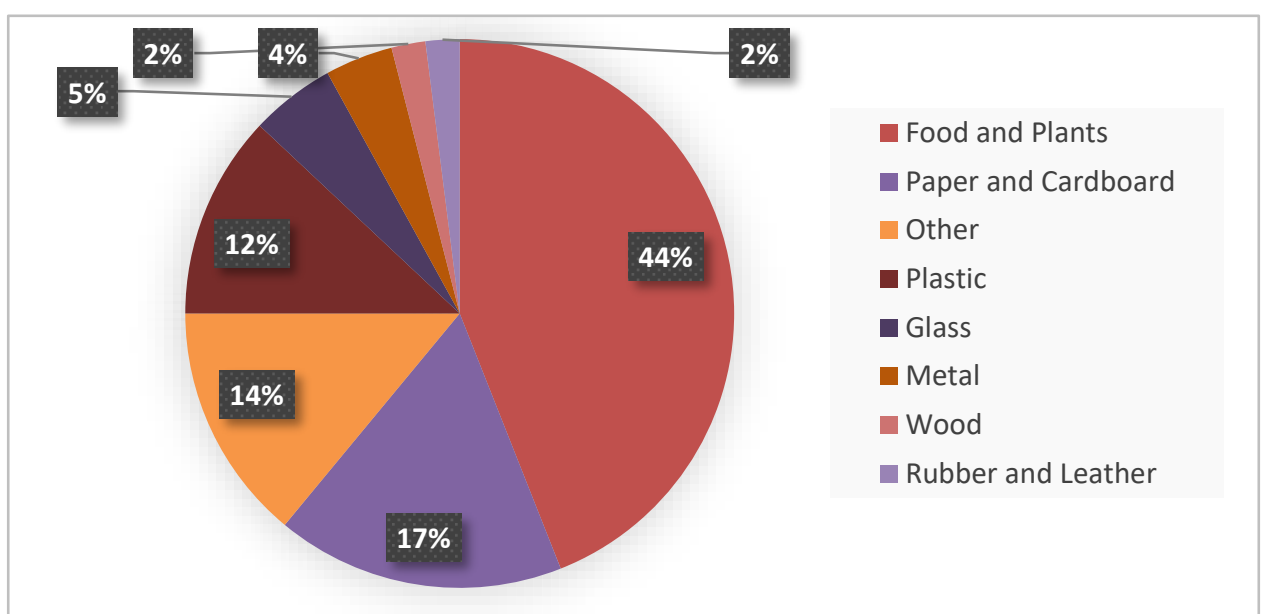

Figure 11. Global distribution of waste types (\%)

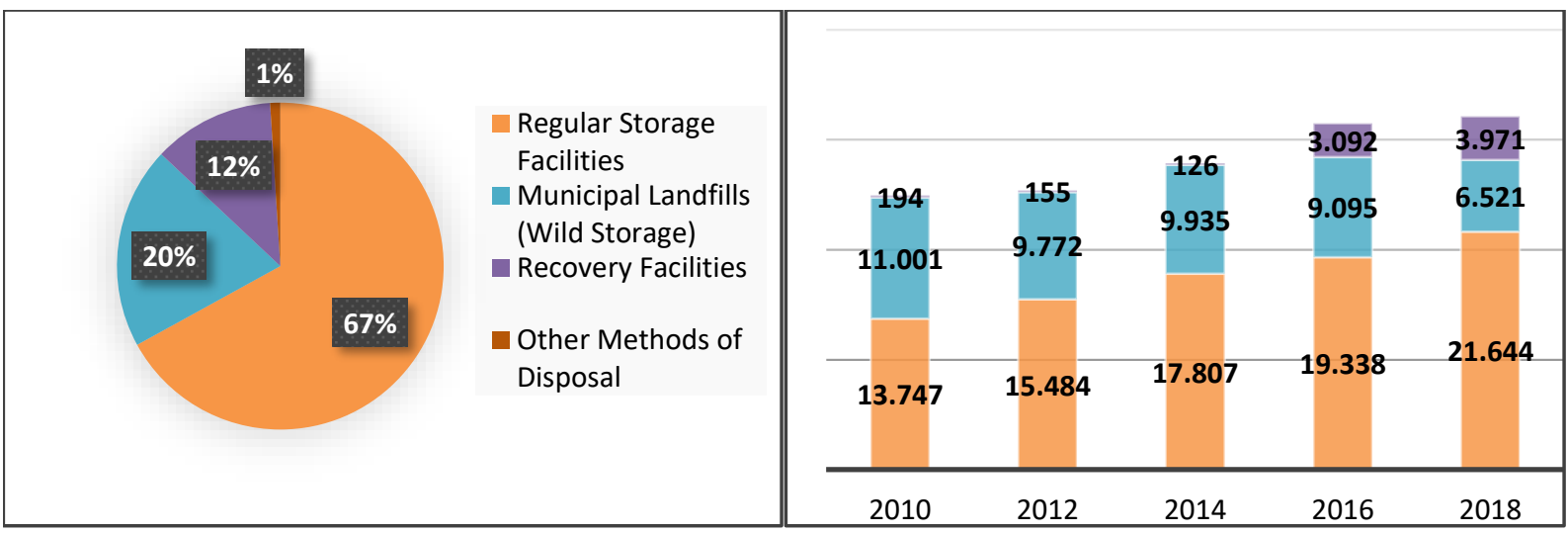


wastes sent to recycling facilities are increasing gradually and the amount of waste in municipal dumps where organic wastes (food wastes such as fruits and vegetables, etc.) are decreasing. The conversion of organic wastes wasted by human beings into energy is proof of their contribution to the fight against climate change when evaluated on the scale of biomass energy.

\section{Conclusion}

Mankind's relationship with natural resources increased with the industrial revolution in the twentieth century. Environmental and climate problems have occurred as a result of being seen nature as an unlimited resource and using it recklessly despite the unlimited needs of mankind. Especially after World War II, the increasing extent of environmental problems; reducing the minimum levels of use of natural resources instead of showing growth activities regardless of developmental purposes, which are in the interest of nature and future generations of the world; has led to the introduction of sustainable development policy within the framework of economic, social and environmental policies. With this policy, existing problems have taken on a new dimension by moving to the international platform.

On a global scale, the energy requested is sourced from fossil sources with limited reserve life and high carbon emissions, which pose a high risk to both energy security and sustainability. The return from fossil energy sources to renewable energy sources is a way to help mitigate climate change. As a matter of fact, the bilateral relationship between sustainable development and renewable energy is important in order to meet the energy needs of future generations.

In particular, we stated that Turkey should reduce its dependence on imports in energy in order to reduce its current account deficit in the economic field, especially considering that it is $90 \%$ dependent on the external energy needs by meeting the energy consumption with the use of fossil fuels such as oil and natural gas. For this reason, the share of renewable energy sources should be further evaluated within the scope of potential superiority and efficiency of biomass energy, which is not particularly dependent on seasonal conditions and is important in zero waste focus. In this context, Turkey; it will have used its geographical superiority and fulfilled its clean environmental obligations by reducing $\mathrm{CO}_{2}$ emissions.

\section{References}

Acaroğlu, M. (2018). Türkiye'de Biyokütle, Biyoetenol ve Biyomotorin Kaynakları ve Biyoyakıt Enerjisinin Geleceği [Biomass, Bioethanol and Biodiesel Energy Sources and Future of Biofuels Energy in Turkey]. In VII. Ulusal Temiz Enerji Sempozyumu (UTES'2008) (pp. 351-362). İstanbul.

Akgül, U. (2010). Sürdürülebilir Kalkınma: Uygulamalı Antropolojinin Eylem Alanı [Sustainable Development:
Action Field of Applied Anthropology]. Antropoloji, 24, 133-164.

Altunok, A. E., \& Altunok, E. (2016). AB İklim Değişikliği Politikaları [EU Climate Change Policies]. Denetişim, 12, 45-55.

https://dergipark.org.tr/tr/pub/denetisim/240323

Ausubel, J.H., \& Biswas, A.K. (1980). Climatic Constraints and Human Activities: Introduction and Overview.

Bahar, H., Feuvre, P. Le, \& Bojek, P. (2020). Bioenergy Power Generation - Analysis - IEA. https://www.iea.org/reports/bioenergy-powergeneration

Bayraç, H.N. (2010). Enerji Kullanımının Küresel Isınmaya Etkisi ve Önleyici Politikalar [Effects of Energy Use on Global Warming and Preventation Policies]. Eskişehir Osmangazi Üniversitesi Sosyal Bilimler Dergisi, 11(2), 229-259.

https://dergipark.org.tr/tr/pub/ogusbd/131623

Bozlağan, R. (2005). Sürdürülebilir Gelişme Düşüncesinin Tarihsel Arka Planı [Historical Background of Sustainable Development Thought]. Sosyal Siyaset Konferansları Dergisi, 50, 1011-1028.

https://dergipark.org.tr/tr/pub/iusskd/9943

British Petroleum. (2020). British Petroleum Statistical Review of World Energy 2020. Statistical Review of World Energy Report. www.bp.com/statisticalreview.

Çamur, D., \& Vaizoğlu, S. A. (2007). Çevreye Ilişkin Önemli Toplantı ve Belgeler [Important Meetings and Documents Concerning Environment]. TSK Koruyucu Hekimlik Bülteni, 6(4).

Çolakoğlu, M., Aslan, S., \& Kumdereli, E. (2021). Biyokütle ve Biyoenerji Sektörlerine Genel Bakış [Overview of the Biomass and Bioenergy Sectors]. pwc. Retrieved from https://www.pwc.com.tr/tr/sektorler/enerji/biyokutleve-biyoenerji-sektorlerine-genel-bakis-web.pdf

Data \& Statistics $\mathrm{CO}_{2}$ emissions, $\mathrm{CO}_{2}$ Emissions by Energy Source - IEA. IEA. (2021). Retrieved from https://www.iea.org/data-and-statistics/databrowser?country=WORLD\&fuel=CO2 emissions.

Doğan, B.B. (2011). Kalkınma İktisadının xx. Yüzyıldaki Gelişim Süreci, İktisat Politikalarına Etkisi ve Son On Yıllık Konjonktürün Disiplinin Geleceğine Olası Etkileri [The Progress of Development Economics in xx. Century, Its Influence on Economic Policies and the Presumptive Effects of the Conjuncture of the Last Decade on the Future of the Discipline]. Kocaeli Üniversitesi Sosyal Bilimler Dergisi, 2(22), 41-83.

https://dergipark.org.tr/tr/pub/kosbed/271177

Freeman, C., \& Soete, L. (2003). Yenilik iktisadı (E. Türkcan, Trans; 2nd Ed.). TÜBITAK.

Global Monitoring Laboratory - Carbon Cycle Greenhouse Gases. Gml.noaa.gov. (2021). Retrieved from https://gml.noaa.gov/ccgg/trends/.

Güzel, Y., İpek, G., Yılmaz, T. Y., Babaoğul, M., Şener, A., Buğday, E. B., \& Yücel, S. (2018). Türkiye israf Raporu [Turkey Waste Report] Tüketicinin Korunması ve Piyasa Gözetimi Genel Müdürlügüu. https://tuketici.ticaret.gov.tr/data/5e6b33e913b876e4 200a0101/Turkiye_Israf_Raporu_2018.pdf

Hardi, P., \& Zdan, T. (1997). Assessing Sustainable Development. International Institute for Sustainable Development.

Hart, M. (1999). Guide to Sustainable Community Indicators (2nd Ed.). Hart Environmental Data. 
IPCC, (2011) Summary for Policymakers. In: IPCC Special Report on Renewable Energy Sources and Climate Change Mitigation [O. Edenhofer, R. Pichs-Madruga, Y. Sokona, K. Seyboth, P. Matschoss, S. Kadner, T. Zwickel, P. Eickemeier, G. Hansen, S. Schlömer, C. von Stechow (eds)], Cambridge University Press, Cambridge, United Kingdom and New York, NY, USA.

IRENA. (2021). Renewable Capacity Statistics 2021. International Renewable Energy Agency (IRENA).

Kanat, Z., \& Keskin, A. (2018). Dünyada İklim Değişikliği Üzerine Yapılan Çalışmalar ve Türkiye'de Mevcut Durum [Studies on Climate Change in the World and Current Situation in Turkey]. Atatürk Univ., J. of the Agricultural Faculty, 49(1), 67-78.

Kaya, M. F., \& Tomal, N. (2011). Sosyal Bilgiler Dersi Öğretim Programının Sürdürülebilir Kalkınma Eğitimi Açısından Incelenmesi [Examination of the Social Sciences Education Program in the Context of Sustainable Development Training]. Eğitim Bilimleri Araştırmaları Dergisi, 1(2), 49-65.

https://dergipark.org.tr/tr/pub/ebader/554597

Keleş, R. (1998). Kentbilim Terimleri SöZlüĞÜ [Glossary of Urban Terms] (2nd ed.). İmge Kitabevi.

Meadows, D.H., Meadows, D.L., Rgen, J. •, William, R., \& Behrens III, W. (1972). The Limits to Growth.

NOAA/ESRL Global Monitoring Laboratory - The NOAA Annual Greenhouse Gas Index (aggi). Gml.noaa.gov. (2021). Retrieved from https://gml.noaa.gov/aggi/.

Özdemir, Y. (2020). Türkiye'nin Enerji Stratejisi [Turkey's Energy Strategy] (pp. 181-186). Nobel Akademik Yayıncilık.

Report of the United Nations Conference on Environment and Development: Vol. I. (1993).

Rydin, Y. (2008). Sustainable Development and Governance. In K. R. CoxM. Low, \& J. Robinson The SAGE handbook of political geography (pp. 579-594). SAGE Publications Ltd, https://www.doi.org/10.4135/9781848607880.n36

Sağsen, I. (2016). Dünyanın Geleceği Üzerine Önemli Bir Viraj: 2015 Paris İklim Değişikliği Zirvesi [An İmportant Turn on the Future of the World: 2015 Paris Climate Change Summit]. Ortadoğu Analiz, 8(72), 72-75.

https://www.academia.edu/21601389/Dünyanın_Gelec eği_Üzerine_Önemli_Bir_Viraj_2015_Paris_iklim_Değişi kliği_Zirvesi

Sera gazı emisyon istatistikleri, 1990-2019. Data.tuik.gov.tr. (2021). https://data.tuik.gov.tr/Bulten/Index?p=SeraGazi-Emisyon-Istatistikleri-1990-2019-37196.

T.C. Enerji ve Tabii Kaynaklar Bakanlığı. (2014). Biyokütle [Biomass]. https://enerji.gov.tr/eigm-yenilenebilirenerji-kaynaklar-biyokutle
https://app.trdizin.gov.tr/makale/TORNMU9USXk/surd urelebilir-kalkinma-yaklasiminin-turkiye-ye-yansimalarigap-ta-surdurulebilir-kalkinma-ve-yerel-gundem-21 https://unfccc.int/process-and-meetings/the-parisagreement/the-paris-agreement

Tester , J. W., Drake, E. M., Driscoll, M. J., Golay, M. W., \& Peters, W. A. (2005). Sustainable energy: choosing among options (2nd Ed.). The MIT Press.

The Paris Agreement / UNFCCC. (2015).

Tıraş, H. H. (2012). Sürdürülebilir Kalkınma ve Çevre: Teorik Bir Inceleme [Sustainable Development and Environment: an Examine in Theory]. Kahramanmaraş Sütçü Imam Üniversitesi iktisadi ve Idari Bilimler Dergisi, 2(2), 57-73.

Türkeş, M. (2000). Hava, İklim, Şiddetli Hava Olayları ve Küresel Isınma [Weather, Climate, Severe Weather Events and Global Warming]. Devlet Meteoroloji Işsleri Genel Müdürlüğ̈̈, 1, 187-205.

Türkiye Elektrik Illetim A.Ş. (2021). Kurulu Güç Raporları [Installed Power Reports]. https://www.teias.gov.tr/trTR/kurulu-guc-raporlari

Türkiye Kojenerasyon Derneği. (nd). Biyokütle nedir [What is biomass]. https://kojenturk.org/tr/biyokutle-nedir-8

UN Documents. (1987). Environment and Development: Our Common Future Towards Sustainable Development 2. part II. Common Challenges Population and Human Resources 4. https://sustainabledevelopment.un.org/content/docu ments/5987our-common-future.pdf

United Nations Conference on Sustainable Development. (2012). A 10-year framework of programmes on sustainable consumption and production patterns (Vol. 12, Issue 37875). https://documents-ddsny.un.org/doc/UNDOC/GEN/N12/378/75/PDF/N123787 5.pdf?OpenElement

United Nations Environment Programme (2021). Food Waste Index Report 2021. Nairobi

World Energy Consumption Statistics / Enerdata. (2020). https://yearbook.enerdata.net/total-energy/worldconsumption-statistics.html

Yıldırım, U., \& Öner, Ş. (2003). Sürdürelebilir Kalkınma Yaklaşımının Türkiye'ye Yansımaları: GAP'ta Sürdürülebilir Kalkınma ve Yerel Gündem 21 [Reflections of Sustainable Development in Approach on Turkey: Sustainable Development in southeastern Anatolia Project and Local Agenda 21]. Çağdaş Yerel Yönetimler, 12(4), 6-27. 